\title{
DESAIN DAN UJI COBA E-MODUL KIMIA BERBASIS PROBLEM SOLVING PADA MATERI LARUTAN PENYANGGA UNTUK KELAS XI SMA SEMESTER II
}

\author{
Indah Julia ${ }^{1)}$, Lisa Utami ${ }^{2)}$ \\ 1)Universitas Islam Negeri Sultan Syarif Kasim Riau \\ 2)Universitas Islam Negeri Sultan Syarif Kasim Riau \\ ${ }^{*}$ Corresponding author. \\ *Email: Indahjulia86@gmail.com; Phone number:+6282258327567
}

\begin{abstract}
Abstrak
Latar belakang dari penelitian ini karena terbatasnya sumber belajar mandiri serta belum adanya sumber belajar yang mengkaitkan materi dengan kehidupan sehari-hari. Untuk itu dalam penelitian ini dirancang desain dan uji coba e-modul dengan pendekatan problem solving dengan software kvisoft flipbook pada materi larutan penyangga. Penelitian ini dilakukan di SMA PGRI Pekanbaru. Penelitian ini menggunakan model pengembangan 4-D sampai tahap develop. Subjek dalam penelitian ini yaitu 1 orang sebagai ahli materi, 1 orang sebagai ahli media, 1 orang guru SMA PGRI Pekanbaru dan 1 orang guru SMAN 5 Tapung sebagai uji praktikalitas media dan 10 orang peserta didik di SMA PGRI Pekanbaru untuk mengetahui respon terhadap media. Data yang diambil dalam penelitian ini adalah berupa wawancara dan angket. Data yang diperoleh kemudian dianalisis dengan teknik analisis deskriptif kualitatif dan deskriptif kuantitatif. Berdasarkan hasil penelitian diperoleh persentase penilaian pada aspek materi sebesar $98,33 \%$ dan media sebesar $95 \%$ dengan kriteria penilaian sangat valid, dan persentase penilaian pada uji praktikalitas peserta didik sebesar $92,8 \%$ dan guru sebesar $93,5 \%$ dengan kriteria penilaian sangat praktis.
\end{abstract}

Kata kunci : E-Modul, Pendekatan Problem Solving, Kvisoft Flipbook, Larutan penyangga

Abstract

The background of this research is due to the limited learning resources that are independent and the lack of learning resources that the connect of material with daily life.Thus, in this research it was designed a design and test of Problem-Solving based chemistry E-Module using Kvisoft Flipbook software on Buffer Solution lesson. This research was administered at SMA PGRI Pekanbaru. 4D development model was used in this research until Develop stage. The subjects of this research were a material validation, a media validation, and 1 teacher at the SMA PGRI Pekanbaru and 1teacher at the SMAN 5 Tapung to test the media practicality, and 10 students of SMA PGRI Pekanbaru were to know the response of the media to know the response of the media. The data were collected through interview and questionnaire. The obtained data then were analyzed by using qualitative and quantitative descriptive analysis techniques. Based on the research finding, it was obtained the assessment on material aspects 98.33\% and by the media 95\%, and they were on very valid criterion. The assessment percentage of student practicality test was $92.8 \%$ and the teacher was $93.5 \%$, they were on very practical criterion.

Keywords: E-Module, Problem Solving Approach, Kvisoft Flipbook, Buffer Solution

\section{Pendahuluan}

Seiring dengan adanya era globalisasi, pelaksanaan pembelajaran saat ini perlu didukung dengan adanya bahan ajar yang berbasis teknologi. Bahan ajar yang berbasis teknologi dapat membuat siswa beradaptasi dengan arus perkembangan di bidang IT. Peraturan Pemerintah Nomor 17 tahun 2010 pasal 48 dan 59 mengisyaratkan di kembangkannya sistem informasi pendidikan yang berbasis teknologi dan informasi. 
Salah satu bahan pembelajaran berbasis teknologi yang dapat dijadikan sebagai penujang adalah E-modul.(Nugroho et al., 2017)

Pada prinsipnya perbedaan antara modul cetak dengan modul elektronik (e-modul) hanya terdapat pada format penyajian secara fisiknya saja, sedangkan komponenkomponen penyusun modul tersebut tidak berbeda(Asmiyunda et al., 2018). Modul yang pada mulanya merupakan media pembelajaran cetak, ditransformasikan penyajiannya ke dalam bentuk elektronik sehingga melahirkan istilah baru yaitu modul elektronik atau e-modul(Mata et al., 2018). E-modul merupakan suatu modul berbasis TIK, kelebihannya adalah sifatnya yang interaktif memudahkan dalam navigasi, memungkinkan menampilkan gambar, audio, video dan animasi(Suarsana \& Mahayukti, 2013). Teks, gambar, animasi, dan video yang terdapat dalam e-modul ini berguna membantu siswa memahami materi kimia dengan baik melalui audio visual(Cahayningrum et al., 2017).

Berdasarkan penelitian yang dilakukan oleh Lalu Bhabiet Rinjani Accraf, bahan ajar yang digunakan guru dalam mengajar masih menggunakan buku paket biasa. Model dan metode yang digunakan guru dalam mengajar masih menonton dan berpusat pada guru sehingga interaksi antara guru dengan siswa masih kurang. Selain itu, pada proses belajar dan pembelajaran kurang menarik karena pemanfaatan media pembelajaran dan sarana laboratorium masih kurang. Hal ini menyebabkan siswa yang belajar masih kurang aktif dan mandiri(Bhabiet et al., 2018).

Penelitian yang juga dilakukan oleh Alvi Sekar Farenta, menyatakan bahwa media yang digunakan selama ini dalam pembelajaran kimia adalah buku paket kurikulum 2013 dari pemerintah, lembar kerja siswa/LKS dan hangout yang disiapkan oleh guru, papan tulis, laptop dan LCD. Kemampuan siswa dalam memahami buku paket serta LKS sangat bervariasi sehingga materi yang disampaikan oleh guru tidak ditangkap secara maksimal oleh siswa(Farenta et al., 2016).

Penggunaan e-modul yang dikembangkan dapat membuat siswa berperan aktif dan membantu siswa dalam pembelajaran kimia. Salah satu pendekatan saintifik yaitu dengan menggunakan model pembelajaran yang menghubungkan pembelajaran kimia dengan kehidupan sehari-hari dan dapat melatih keterampilan berpikir kreatif siswa adalah model pembelajaran problem solving(Ulya et al., 2017). Problem solving adalah sebuah cara membelajarkan siswa yang difokuskan pada suatu masalah atau isu untuk dianalisis dan dipecahkan sehingga diperoleh suatu kesimpulan(supriadie didi, 2012). Dengan menggunakan pembelajaran yang berbasis problem solving, maka siswa dapat mengkaitakan antara pengetahuan konsep dengan keterampilan secara sinergi.

Ayat Al-Quran pada surah An-Nahl ayat 89 dijelaskan tentang media yang berbunyi:

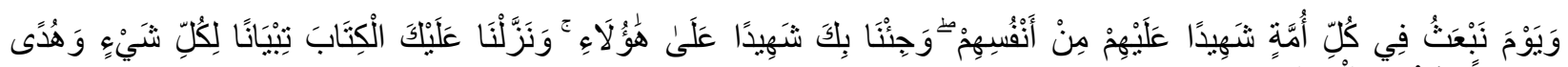
Artinya : 
"(Dan ingatlah) akan hari (ketika) kami bangkitkan pada tiap-tiap umat seorang saksi atas mereka dari mereka sendiri dan kami datangkan kamu (Muhammad) menjadi saksi atas seluruh umat manusia. Dan kami turunkan kepadamu Al Kitab (Al Quran) untuk menjelaskan segala sesuatu dan petunjuk serta rahmat dan kabar gembira bagi orangorang yang berserah diri."(Al-Qur'an, n.d.)

Ayat ini secara tidak langsung Allah mengajarkan kepada manusia untuk menggunakan sebuah alat/benda sebagai suatu media dalam menjelaskan segala sesuatu. Sebagaimana Allah SWT menurunkan Al Quran kepada Nabi Muhammad SAW untuk menjelaskan segala sesuatu, maka sudah sepatutnya jika seorang menggunakan suatu media tertentu dalam menjelaskan segala hal(Al-imam, 2002).

Media yang dapat mendukung dalam e-modul ini yaitu menggunakan Software Kvisoft Flipbook. Kvisoft Flipbook merupakan multimedia yang dapat mengombinasikan slide, audio, grafik, teks, suara, video, dan animasi(Mulyaningsih \& Saraswati, 2017). Ditingkat SMA pada kelompok peminatan MIPA, mata pelajaran khususnya kimia dipandang penting untuk diajarkan sebagai mata pelajaran tersendiri. Karakteristik konsep ilmu kimia yang merupakan salah satu ilmu pasti, berbeda dengan konsep ilmu lainnya. Tujuan mata pelajaran kimia salah satunya adalah menerapkan konsep-konsep kimia untuk menyelesaikan masalah dalam kehidupan sehari-hari dan teknologi(Farenta et al., 2016).

Didukung penelitian Resti ana marsita yang menyebutkan bahwa faktor-faktor penyebab kesulitan siswa dalam memahami materi larutan penyangga, yaitu kurangnya minat dan perhatian siswa pada saat proses pembelajaran berlangsung, kurangnya kesiapan siswa dalam menerima konsep baru, konsep-konsep penting yang merupakan konsep prasyarat untuk mempelajari konsep selanjutnya, dan penanaman konsep yang kurang mendalam(Marsita et al., 2011).

Berdasarkan hasil survei lapangan dengan melakukan wawancara kepada guru kimia di SMA PGRI Pekanbaru diperoleh informasi bahwa dalam proses pembelajaran kimia belum adanya pengembangan e-modul sebagai media pembelajaran, padahal sekolah telah memiliki berbagai fasilitas yang memungkinkan pembelajaran berbantu media kvisoft flipbook maker. Sumber belajar yang digunakan oleh peserta didik dalam pembelajaran kimia berupa powerpoint dan buku paket dari sekolah, tetapi buku tersebut hanya digunakan pada proses pembelajaran saja tidak dibawa pulang oleh peserta didik.

Mengatasi masalah tersebut, penulis melakukan penelitian pengembangan sumber belajar siswa berupa e-modul. Hal inilah yang menjadi alasan bagi penulis untuk melakukan penelitian ini. 


\section{Metode}

Penelitian ini merupakan suatu penelitian dan pengembangan atau dikenal dengan nama Research and Development (R\&D). Penelitian dan pengembangan adalah metode penelitian yang digunakan untuk menghasilkan produk tertentu, dan menguji keefektifan produk tersebut(sugiyono, 2015). Penelitian ini dilaksanakan di SMA PGRI Pekanbaru dan SMAN 5 TAPUNG pada semester ganjil tahun pelajaran 2019/2020. Objek penelitian ini adalah media pembelajaran e-modul kimia berbasis problem solving pada materi larutan penyangga. Subyek penelitian ini adalah pihak yang melakukan validasi terhadap produk e-modul yang dihasilkan yaitu ahli desain media pembelajaran, ahli materi pembelajaran dan guru kimia di SMA PGRI Pekanbaru dan di SMAN 5 TAPUNG

Model pengembangan dalam penelitian ini adalah model pengembangan 4-D (four D) merupakan model pengembangan perangkat pembelajaran. Model pengembangan 4D terdiri atas 4 tahap utama yaitu: (1) Pendefinisian (Define), (2) Perancangan (Design), (3) Pengembangan (Development), dan (4)Penyebaran (Disseminate)(Kintoko et al., 2015). Namun, pada penelitian ini peneliti hanya melakukan penelitian sampai pada tahap ketiga yaitu tahap development bagian revisi dan uji coba produk skala kecil.

Teknik yang digunakan untuk mengumpulkan data dalam penelitian ini adalah angket. Kuesioner atau angket adalah alat untuk mengumpulkan informasi dengan cara menyampaikan beberapa pertanyaan dan jawaban tertulis(hadi amirul, 1998). Angket yang digunakan dalam penelitian ini adalah angket uji validitas dan angket uji coba terbatas. Dimana, angket ini menggunakan Tipe rating scale. Tipe rating scale untuk melihat persepsi dari ahli materi, ahli media, guru, dan peserta didik. Pengubahan hasil penilaian uji validitas (ahli materi dan ahli media) dan uji praktikalitas (guru dan peserta didik)dengan skala likert dapat dilihat pada tabel I(hadi amirul, 1998).

\begin{tabular}{cc}
\multicolumn{2}{c}{ Tabel I. Aturan Pemberian Skor } \\
\hline Kategori & Skor \\
\hline Sangat Baik & 5 \\
\hline Baik & 4 \\
\hline Sedang & 3 \\
\hline Kurang & 2 \\
\hline Sangat Kurang & 1 \\
\hline
\end{tabular}

Teknik analisis data pada peneitian ini adalah analisis deskriptif kualitatif dan analisis data kuantitatif. Analisis deskriptif kualitatif dilakukan dengan mengelompokkan saran yang terdapat pada angket baik pada saat uji validitas media pembelajaran maupun uji praktikalitas. Sedangkan analisis deskriptif kuantitatif yang mendeskripsikan hasil uji validitas dan uji praktikalitas(hadi amirul, 1998).

Untuk melakukan analisis validitas/praktikalitas e-modul yang dikembangkan digunakan rating scale diperoleh dengan cara:

1. Menentukan skor maksimal ideal 
Skor maksimal ideal = skor maksimal tiap item $\mathrm{x}$ jumlah butir komponen

2. Menentukan skor yang diperoleh dengan menjumlahkan skor dari masing-masing validator

3. Menentukan persentase keidealan/ kepraktisan

$$
\% \text { Keidealan } / \text { kepraktisan }=\frac{\Sigma S}{S M} X 100 \%
$$

Keterangan:

$\mathrm{NP}$ : Nilai persen yang dicari atau diharapkan

$\Sigma S$ : Jumlah skor yang diperoleh

SM : Skor Maksimal

Hasil persentase kemudian di tafsirkan dalam pengertian kualitatif berdasarkan tabel II dan III berikut ini :

Tabel II. Persentase Tingkat Kevalidan Produk

\begin{tabular}{ccc}
\hline No & Interval skor & Kategori \\
\hline 1 & $81-100 \%$ & Sangat Valid \\
\hline 2 & $61-80 \%$ & Valid \\
\hline 3 & $41-60 \%$ & Cukup Valid \\
\hline 4 & $21-40 \%$ & Kurang Valid \\
\hline 5 & $0-20 \%$ & Sangat Kurang Valid \\
\hline
\end{tabular}

Tabel III. Persentase Tingkat Kepraktisan Produk

\begin{tabular}{ccc}
\hline No & Interval skor & Kategori \\
\hline 1 & $81-100 \%$ & Sangat Praktis \\
\hline 2 & $61-80 \%$ & Praktis \\
\hline 3 & $41-60 \%$ & Cukup Praktis \\
\hline 4 & $21-40 \%$ & Kurang Praktis \\
\hline 5 & $0-20 \%$ & Sangat Kurang Praktis \\
\hline
\end{tabular}

(Riduwan, 2014)

\section{Hasil dan Pembahasan}

Hasil penelitian yang dilaksanakan berdasarkan langkah-langkah prosedur pengembangan 4-D adalah sebagai berikut:

\section{Tahap Pendefinisian (Define)}

Tahap ini bertujuan untuk mendefenisikan dan menetapkan syarat-syarat pembelajaran. Tahapan pada pendefinisian dengan melakukan survei lapangan untuk pengumpulkan informasi sehingga peneliti mengetahui permasalahan dan mengetahui kebutuhan peserta didik terhadap produk yang akan dikembangkan. Analisis ini dilakukan dengan melalui beberapa langkah yaitu:

\section{a. Analisis Kurikulum}

Tahap ini untuk mengetahui kurikulum yang digunakan pada sekolah sehingga dapat menetapkan kompetensi yang akan dicapai pada bahan ajar yang ingin dikembangkan, karena tidak semua kompetensi yang ada pada kurikulum akan ada 
bahan ajar. Hasil wawancara dengan guru disimpulkan bahwa kurikulum yang digunakan di sekolah tersebut sudah menerapkan kurikulum 2013.

\section{b. Analisis Peserta Didik}

Analisis peserta didik dilakukan untuk mengetahui karakteristik peserta didik yang sesuai dengan racangan dan pengembangan bahan pembelajaran. Dari hasil observasi diperoleh data tentang karakteristik peserta didik sebagai berikut : (1) Usia rata-rata peserta didik yang menjadi subjek penelitian adalah 16-17 tahun, dimana pada usia ini peserta didik sudah dapat berfikir logis serta dapat mengembangkan kemampuan bernalar dengan cara yang lebih abstrak dan idealistis. (2) Berdasarkan telaah kemampuan awal peserta didik dilihat dari hasil belajar yang diperoleh pada materi prasyarat untuk mempelajari materi larutan penyangga telah tuntas. Walaupun demikian guru masih perlu mengingatkan kembali materi tersebut diawal pertemuan. (3) Gaya belajar peserta didik juga bervariasi, tetapi yang paling dominan adalah gaya belajar visual yakni belajar dengan mengutamakan indra penglihatan. Peserta didik lebih tertarik belajar jika divisualisasikan, baik melalui gambar maupun dialami secara langsung ( melalui pratikum), dan diperlihatkan dengan hal-hal yang berkaitan dengan kehidupan sehari-hari.

\section{c. Analisis Materi}

Kegiatan yang dilakukan pada langkah ini adalah mengidentifikasi, merinci dan menyusun secara sistematis materi-materi utama yang akan dipelajari peserta didik. Materi utama dalam pembelajaran dalam penelitian ini adalah materi larutan penyangga dengan kompetensi dasar, 3.12 menjelaskan prinsip kerja, perhitungan $\mathrm{pH}$, dan peran larutan penyangga dalam tubuh mahluk hidup dan 4.12 membuat larutan penyangga dengan $\mathrm{pH}$ tertentu. Garis-garis besar materi adalah (1) Pengertian larautan penyangga, (2) Sifat larutan penyangga (3) Komponen larutan penyangga, (4) Prinsip kerja larutan penyanga, (5) $\mathrm{pH}$ larutan penyangga, (6) Pembuatan larutan penyangga, dan (7) Larutan penyangga dalam tubuh mahluk hidup dan kehidupan sehari-hari.

\section{d. Merumuskan Tujuan}

Hasil analisis spesifikasi tujuan pembelajaran pada materi larutan penyangga adalah : (1) Menjelaskan pengertian larutan penyangga, (2) Menjelaskan sifat larutan penyangga, (3) Mengklasifikasikan larutan penyangga dan bukan larutan penyangga berdasarkan hasil percobaan, (4) Mengklasifikasikan larutan penyangga kedalam penyangga asam dan penyangga basa, (5) Mengidentifikasi komponen larutan penyangga asam dan larutan penyangga basa, (6) Menganalisis cara kerja larutan penyangga dalam mempertahankan pHnya terhadap penambahan sedikit asam atau basa atau pengenceran, (7) menghitung $\mathrm{pH}$ larutan penyangga dengan penambahan sedikit asam, basa atau pengenceran, (8) Menghitung $\mathrm{pH}$ larutan penyangga yang terbentuk dari reaksi antara asam lemah berlebih dengan basa kuat, (9) Menghitung $\mathrm{pH}$ larutan penyangga yang terbentuk dari reaksi antara basa lemah berlebih dengan 
asam kuat, (10) Menjelaskan fungsi larutan penyangga dalam tubuh makhluk hidup, dan (12) Menjelaskan fungsi larutan penyangga dalam kehidupan sehari-hari.

\section{Tahap Perancangan (Design)}

Tahap perancangan bertujuan untuk meyiapkan kerangka e-modul.Tahap perancangan ini akan dirumuskan berdasarkan studi awal yang telah diketahui serta mempertimbangkan karakteristik peserta didik. Dari hasil pertimbangan tersebut, maka media yang dirasa cocok digunakan untuk materi larutan penyangga adalah media pembelajaran e-modul berbasis problem solving seperti yang telah dijelaskan sebelumnya. Pada tahap perancangan ini yang peneliti lakukan adalah:

\section{a. Pembuatan Storyboard}

Storyboard merupakan deskripsi tiap scene (tampilan) dengan mencantumkan semua elemen multimedia seperti animasi, teks, gambar, dan video; serta link ke scene lainnya. Storyboard disusun dengan menyesuaikan dengan instrumen dari penilaian media pembelajaran. Untuk materi yang dimuat dalam storyboard ini disesuaikan dengan kompetensi inti, kompetensi dasar, indikator pencapaian kompetensi, dan tujuan pembelajaran yang telah dirumuskan sebelumnya.

\section{b. Desain Produk Awal}

Pada tahap perancangan produk awal ini, dihasilkanlah media pembelajaran yang sesuai dengan rancangan awal yang telah dibuat melalui penyusunan storyboard. Sehingga dihasilkan rancangan awal berupa cover, petunjuk penggunaan, dan pendektan problem solving.

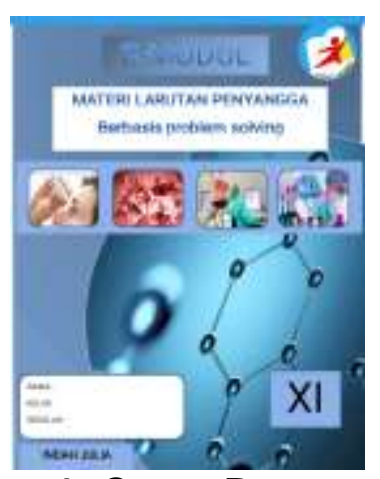

Gambar 1. Cover Rancangan Awal

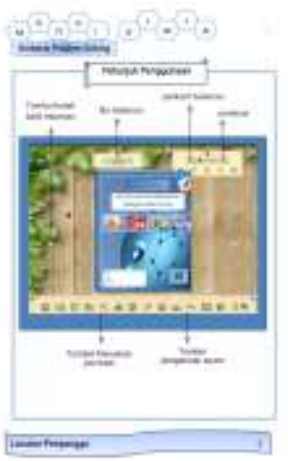

Gambar 2. Petunjuk Penggunaan 

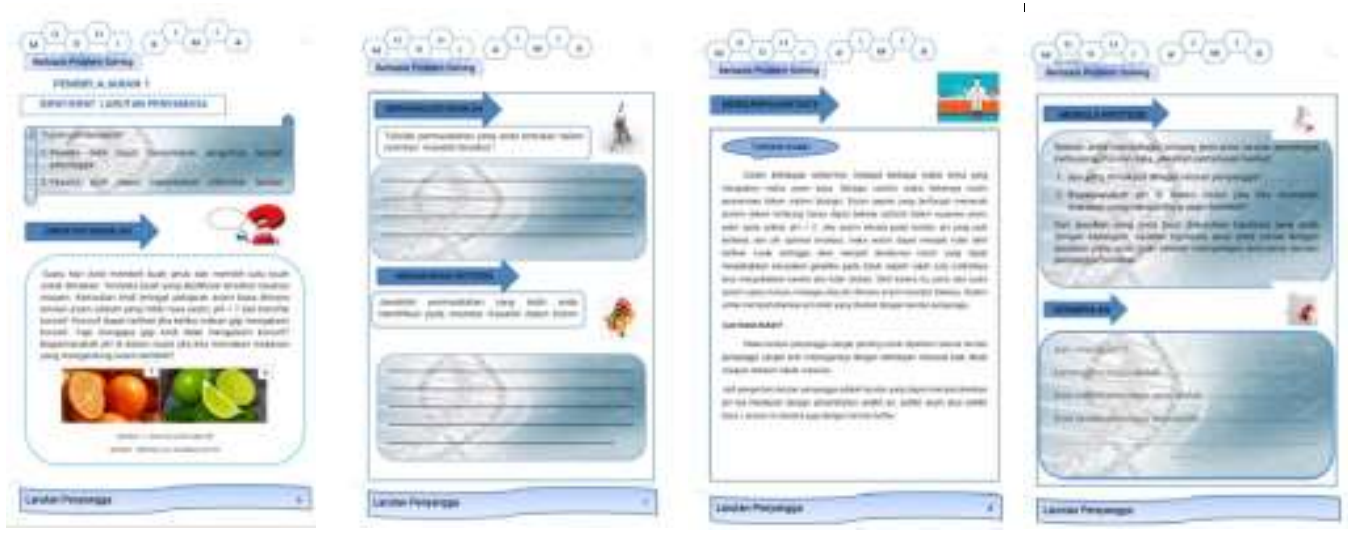

Gambar 3. Pendekatan Probem Solving

\section{Tahap Pengembangaan (Develop)}

Tujuan dari tahap ini adalah untuk menghasilkan perangkat pembelajaran yang sudah direvisi berdasarkan masukan dari pakar. Tahap ini terdiri dari :

\section{a. Validasi E-Modul}

Validasi e-modul ini dilakukan oleh 2 orang pakar atau ahli yang terdiri dari satu orang ahli materi pembelajaran dan satu orang ahli media pembelajaran yang disebut juga dengan validator.

Tahap validasi dilakukan dengan cara meminta pendapat dari pakar atau ahli untuk menilai produk yang dihasilkan, sehingga dapat diketahui kelemahan dan kekuatan dari media tersebut. Teknik yang digunakan adalah dengan menggunakan metode angket. Angket yang digunakan telah divalidasi oleh validator ahli instrumen, persentase dari penilaian yang diberikan sudah termasuk kategori "sangat valid". Dengan demikian maka instrument angket tersebut sudah dapat digunakan untuk menilai media e-modul. Adapun hasil penilaian tersebut adalah sebagai berikut:

\section{Ahli Materi Pembelajaran}

Validasi produk oleh ahli materi pembelajaran dilakukan dengan menunjukkan dan menjelaskan tentang produk media pembelajaran berupa e-modul kepada ahli materi yaitu ibu Dra. Fitri Refelita, M. Si. Selaku dosen Pendidikan Kimia di UIN SUSKA Riau. Menurut beliau produk ini layak digunakan untuk pembelajaran kimia. Saran yang diberikan validator terhadap e-modul hasil pengembangan yaitu menggunakan bahasa yang mudah dimengerti dan memberikan penjelasan disetiap gambar. Hasil penilaian dapat dilihat pada Tabel IV.

Tabel IV. Hasil Uji Validitas Ahli Materi

\begin{tabular}{llll}
\hline No & \multicolumn{1}{c}{ Aspek } & Persentase & Kriteria \\
\hline 1 & Kelayakan isi & $100 \%$ & Sangat valid \\
\hline 2 & Penyajian & $100 \%$ & Sangat valid \\
\hline 3 & Kebahasaan & $93 \%$ & Sangat valid \\
\hline 4 & Pendekatan problem solving & $100 \%$ & Sangat valid \\
\hline \multicolumn{2}{c}{ Rata-rata } & $98.25 \%$ & Sangat valid \\
\hline
\end{tabular}


Media e-modul berbasis problem solving termasuk kategori sangat valid dengan persentase kevalidannya sebesar $98,25 \%$ dan layak untuk diuji cobakan karena berada pada rentang $81 \%$ sampai $100 \%$.

\section{Ahli Desain Media}

Validasi produk oleh ahli media dilakukan dengan menunjukkan dan menjelaskan tentang produk media pembelajaran berupa e-modul dengan pendekatan problem solving kepada satu orang ahli desain media yaitu bapak Dr. Kuncoro Hadi, S. Si., M. Sc, selaku dosen Pendidikan Kimia di UIN SUSKA Riau. Menurut beliau produk ini layak digunakan untuk pembelajaran kimia. Saran yang diberikan validator terhadap e-modul hasil pengembangan yaitu adanya kesalahan penulisan dan sertakan program pendukungnya. Hasil penilaian dapat dilihat pada tabel V.

Tabel V. Hasil Uji Validitas Ahli Media

\begin{tabular}{llll}
\hline No & \multicolumn{1}{c}{ Aspek } & Persentase & Kriteria \\
\hline 1 & Cover & $100 \%$ & Sangat valid \\
\hline 2 & Isi & $100 \%$ & Sangat valid \\
\hline 3 & Kebahasaan & $100 \%$ & Sangat valid \\
\hline 4 & Kepraktisan & $100 \%$ & Sangat valid \\
\hline 5 & Penggunaan gambar/video & $100 \%$ & Sangat valid \\
\hline 6 & Pengoperasian & $60 \%$ & Cukup valid \\
\hline & Rata-rata & $93.3 \%$ & Sangat valid
\end{tabular}

Media e-modul berbasis problem solving termasuk kategori sangat valid dengan persentase kevalidannya sebesar $93,33 \%$ dan layak untuk diuji cobakan karena berada pada rentang $81 \%$ sampai $100 \%$.

\section{b. Uji coba praktikalitas media e-modul}

\section{Uji Praktikalitas Guru}

Hasil uji coba diperoleh melalui pengisian angket guna untuk mengetahui respon dari guru kimia terhadap media pembelajaran e-modul yang dihasilkan. Angket uji coba ini diisi oleh guru kimia setelah membaca dan memahami media pembelajaran e-modul dengan pendekatan problem solving. Hasil penilaiannya dapat dilihat pada tabel VI.

Tabel VI. Hasil Uji Praktikalitas Oleh Guru

\begin{tabular}{llll}
\hline No & \multicolumn{1}{c}{ Aspek } & Persentase & Kriteria \\
\hline 1 & Kegrafikan & $97.5 \%$ & Sangat praktis \\
\hline 2 & Isi & $100 \%$ & Sangat praktis \\
\hline 3 & Penyajian & $93,3 \%$ & Sangat praktis \\
\hline 4 & Bahasa & $93.3 \%$ & Sangat praktis \\
\hline 5 & Pendekatan problem soving & $86,6 \%$ & Sangat praktis \\
\hline & Rata-rata & $94.14 \%$ & Sangat praktis \\
\hline
\end{tabular}


Media e-modul berbasis problem solving termasuk kategori sangat praktis dengan persentase praktikalitannya sebesar $94,14 \%$ dan layak untuk diuji cobakan karena berada pada tentang $81 \%$ sampai $100 \%$.

\section{Uji Coba Terbatas Terhadap Respon Peserta Didik}

Setelah media pembelajaran e-modul dengan pendekatan problem solving divalidasi oleh ahli materi dan ahli media serta telah diuji kepraktisannya oleh guru kimia, langkah selanjutnya dengan melakukan uji coba terbatas terhadap 10 orang peserta didik kelas XII IPA SMA PGRI Pekanbaru. Hasil penilaiannya dapat dilihat pada tabel VII.

Tabel VII. Hasil Uji Praktikalitas Oleh Peserta Didik

\begin{tabular}{llll}
\hline No & \multicolumn{1}{c}{ Aspek } & Persentase & Kriteria \\
\hline 1 & Penyajian & $94.5 \%$ & Sangat praktis \\
\hline 2 & Ketertarikan & $91.1 \%$ & Sangat praktis \\
\hline & Rata-rata & $92.8 \%$ & Sangat praktis
\end{tabular}

Hasil penilaian oleh validator uji praktikalitas menunjukkan bahwa e-modul kimia berbasis problem solving secara keseluruhan sangat praktis dalam menyampaikan materi larutan penyangga.

\section{Kesimpulan}

Berdasarkan hasil penelitian yang telah dilakukan, maka dapat diambil kesimpulan yaitu : Tingkat validitas e-modul berbasis problem solving pada materi kimia larutan penyangga yaitu sebesar $98,25 \%$ (ahli materi) dengan kategori sangat valid dan 93,33\% (ahli media) dengan kategori sangat valid, Sedangkan Tingkat praktikalitas e-modul berbasis problem solving pada materi kimia larutan penyangga yaitu sebesar 94,14\% (guru) dengan kategori sangat praktis dan 92,8\% (peserta didik) kategori sangat praktis digunakan dalam pembelajaran.

\section{Daftar Referensi}

Al-imam, A. F. D. (2002). Terjemahan Tafsir Ibnu Katsir Jus 14. Sinar Baru AlGensindo.

Al-Qur'an. (n.d.). Surah An-nahl ayat 89.

Asmiyunda, A., Guspatni, G., \& Azra, F. (2018). Pengembangan E-Modul Kesetimbangan Kimia Berbasis Pendekatan Saintifik untuk Kelas XI SMA/ MA. Jurnal Eksakta Pendidikan (Jep), 2(2), 155. https://doi.org/10.24036/jep/vol2iss $2 / 202$

Bhabiet, L., Accraf, R., Khery, Y., Kimia, P. P., Mataram, I., \& No, J. P. (2018). PENGEMBANGAN E-MODUL INTERAKTIF BERBASIS ANDROID DAN NATURE OF SCIENCE PADA MATERI IKATAN KIMIA DAN SAINS SISWA Skor Rata- Skor Rata- Peringka a I ndonesia Internasional karakter ilmiah . Memahami Nature of Science (NOS ) merupakan bagian penting dari li. 6(2).

Cahayningrum, R. D., Nurjayadi, M., \& Rahman, A. (2017). Pengembangan E-Module Kimia Berbasis Pogil (Process Oriented Guided Inquiry Learning) Pada Materi Reaksi Reduksi-Oksidasi Sebagai Sumber Belajar Siswa. JRPK: Jurnal Riset 
Pendidikan Kimia, 7(1), 59-65. https://doi.org/10.21009/jrpk.071.07

Farenta, A., Sulton, S., \& Setyosari, P. (2016). Pengembangan E-Module Berbasis Problem Based Learning Mata Pelajaran Kimia Untuk Siswa Kelas X Sma Negeri 8 Malang. Jurnal Pendidikan - Teori, Penelitian, Dan Pengembangan, 1(6), 11591168. https://doi.org/10.17977/jp.v1i6.6460

hadi amirul. (1998). Metodologi penelitian. Pustaka Setia.

Kintoko, Sujadi, I., \& Sari, D. R. (2015). Pengembangan Media Pembelajaran Matematika Berbantuan Komputer dengan Lectora Authoring Tools pada Materi Bangun Ruang Sisi Datar Kelas VIII SMP/MTS. Jurnal Elektronik Pembelajaran Matematika, 3(2), 167-178.

Marsita, R. A., Priatmoko, S., \& Kusuma, E. (2011). Analisis Kesulitan Belajar Kimia Siswa Sma Dalam Memahami Materi Larutan Penyangga Dengan Menggunakan Two-Tier Multiple Choice Diagnostic Instrument. Jurnal Inovasi Pendidikan Kimia, 4(1), 512-520.

Mata, P., Sistem, K., \& Pembelajaran, E. (2018). Pengembangan E-Modul Interaktif Berbasis Proyek Matematika. 4(2), 57-63.

Mulyaningsih, N. N., \& Saraswati, D. L. (2017). Penerapan Media Pembelajaran Digital Book Dengan Kvisoft Flipbook Maker. JPF Jurnal Pendidikan Fisika, V(1), 25-32.

Nugroho, K. M., Raharjo, S. B., \& Masykuri, M. (2017). Pengembangan E-Modul Kimia Berbasis Problem Solving Dengan Menggunakan Moodle Pada Materi Hidrolisis Garam Untuk Kelas XI SMA/MA SEMESTER II. Http://Jurnal.Uns.Ac.Id/Inkuiri, 6(1), 175-180.

Riduwan. (2014). Skala penilaian. Alfabeta.

Suarsana, I. M., \& Mahayukti, G. A. (2013). Pengembangan E-Modul Berorientasi Pemecahan Masalah Untuk Meningkatkan Keterampilan Berpikir Kritis Mahasiswa. Jurnal Nasional Pendidikan Teknik Informatika (JANAPATI), 2(3), 193. https://doi.org/10.23887/janapati.v2i3.9800

sugiyono. (2015). Metode penelitian pendidikan: pendekatan kuantitatif, kualitatif, dan $R \& D$. Alfabeta.

supriadie didi, darmawan deni. (2012). Komunikasi pembelajaran. PT. Remaja Rosdakarya.

Ulya, H., Rudibyani, R. B., \& Efkar, T. (2017). Pengembangan Modul Kimia Berbasis Problem Solving Pada Materi Asam Basa Arrhenius. Jurnal Pendidikan Dan Pembelajaran Kimia, 7(1), 129-141. 